\title{
Additions and amendments to the list of Estonian bryophytes
}

\author{
Kai Vellak ${ }^{1,2}$, Rut Caparrós Callejo ${ }^{3}$, Nele Ingerpuu ${ }^{1}$, Mare Leis ${ }^{4}$, \\ Loore Ehrlich ${ }^{5}$, Tiiu Kupper ${ }^{2}$ \\ ${ }^{1}$ University of Tartu, Institute of Ecology and Earth Sciences, Lai 40, 51005 Tartu, Estonia \\ E-mail: kai.vellak@ut.ee \\ ${ }^{2}$ University of Tartu, Natural History Museum, Vanemuise 46, 51014 Tartu, Estonia \\ ${ }^{3}$ Universidad Autónoma de Madrid, Ciudad Universitaria de Cantoblanco, Facultad de Ciencias, \\ Dpto. Botánica, Calle Darwin 2, 28048 Madrid, Spain \\ ${ }^{4}$ Estonian University of Life Sciences, Institute of Agricultural and Environmental Sciences, \\ Kreutzwaldi 5, 51014 Tartu, Estonia \\ ${ }^{5}$ Estonian Museum of Natural History, Lai 29A, 10133 Tallinn, Estonia
}

\begin{abstract}
Five new moss species and one variety are incorporated to the Estonian bryoflora, one species should be eliminated due to recent taxonomical study. The number of bryophyte species has now risen to 602 for Estonia, thus the number of species has doubled since the first published list in 1860.
\end{abstract}

Keywords: bryoflora, Estonia, new species, voucher specimens

\section{INTRODUCTION}

Five new moss species and one variety are incorporated to the Estonian bryoflora since the last additions (Vellak et al., 2017), and one previously known species is excluded from the list. The number of Estonian bryophyte species has doubled since the first published checklist of Estonian bryophytes (Girgensohn, 1860), and the list of Estonian bryophytes contains now 602 species. One species and one variety new for Estonia have been identified from earlier herbarium specimens, whereas four species are added due to recent taxonomical studies (Hassel et al., 2018; Caparrós et al., 2016) that include also Estonian material.

All four bryophyte herbaria in Estonia - TAA, TAM, TALL and TU - were inspected to clarify the distribution of these new species in Estonia. Below we present the first records of new taxa of Estonian bryoflora. In addition, new voucher specimens for four species are presented here, since their previous vouchers were re-identified.

\section{RESULTS AND DISCUSSION}

The latest molecular studies showed that Sphagnum magellanicum Brid., a species that was considered to be one of the most widely distributed peatmoss in the world until now, is a complex species, and includes actually three different species - S. magellanicum s.str., $S$. medium Limpr., and S. divinum Flatberg \& Hassel. The distribution of $S$. magellanicum s.str. is restricted only to southern South America, while two others, S. medium and $S$. divinum occur in Northern Hemisphere (Hassel et al., 2018). The study by Hassel et al. (2018) included also material from Estonia and the occurrence of $S$. divinum and $S$. medium in Estonia has been proven. Sphagnum magellanicum (in Estonian 'lillakas turbasammal' - 'purple peatmoss') has been the best-known peatmoss in Estonia for a long time, but since this species in sensu stricto does not belong to Estonian bryoflora anymore, its Estonian name was changed to 'patagoonia turbasammal' ('patagonian peatmoss') which points to its actual distribution.

First data about the occurrence of $S$. medium in Estonia was published already in the $19^{\text {th }}$ century, and the species was characterized then as widely distributed in North Estonian raised bogs (Russow, 1894). According to the examined herbarium material, S. medium and S. divinum both are frequent, occurring over the whole territory of Estonia. Sphagnum medium obviously prefers to grow in open bogs, along bog pool margins and in lawns, whereas $S$. divinum grows mainly in bog forests and shaded transitional mires. 
One more taxonomical study done by Caparrós et al. (2016), gave two new species to Estonian bryoflora. Based on the sporophyte characteristics as well as on the analysis of nuclear and plastid loci, Ulota crispa (Hedw.) Brid. complex was splitted into three species - Ulota crispa s.str., U. crispula Bruch. and U. intermedia Schimp. Among the examined specimens, one specimen was from the exsiccate collection of $\mathrm{J}$. Mikutowicz, collected in 1909 from Estonia. The specimen (TU171437) was originally labelled as U. bruchii Hornsch. ex Brid. but was re-identified as U. crispula Bruch (Caparrós et al., 2016). We checked the whole J. Mikutowicz collection deposited in TU and found one specimen identified as $U$. crispula by him in 1911 (TU171434). We examined the specimen according to the new concept of species approach, and the original identification was confirmed. So, being meanwhile joint with $U$. crispa (Rosman-Hartog \& Touw, 1987), the occurrence of $U$. crispula in Estonia is documented already since 1911, from Lehola (Harju County).

To ascertain the occurrence of $U$. intermedia - another species of the U. crispa-group, and to clarify the distribution of these three Ulota species in Estonia, all specimens labelled as $U$. crispa were checked in four Estonian herbaria. The examination revealed that $U$. intermedia is the most frequent species and is distributed over the whole territory. Ulota crispula is distributed sporadically in Estonia, but U. crispa, formerly known to be common over the whole territory, appeared to be rare in Estonia having solitary findings only in southwestern part of Estonia. The voucher specimen designated for $U$. crispa was reassigned to $U$. intermedia and a new voucher specimen for $U$. crispa was selected (see below).

The occurrence of one species, Dicranella rufescens (Dicks.) Schimp. in Estonia was formerly based only on literature data (Vellak et al., 2015). While working in the Herbarium of the Latvian University (RIG), we found a specimen that was cited by Malta (1930). Thus, the occurrences of all bryophyte taxa in Estonia are now based on checked voucher specimens.

For two species - Atrichum crispum and Plagiothecium latebricola new voucher specimens are presented here, because of re-identification of previous ones.

\section{New taxa for Estonia}

ORTHOTRICHUM STRIATUM Hedw. [tünntutik]

Voucher specimen: TALL D019627, Pärnu Co., Saarde Comm., Kõveri village, farm yard, on a stone $\left(58.1577^{\circ} \mathrm{N}, 24.67468^{\circ} \mathrm{E}\right)$, leg. L. Kannukene, 07 June 1997; det. M. Leis, 25 Jan 2019. Duplicates in TU, TAA.

The distribution area of Orthotrichum striatum covers area from Europe to North Africa, Asia and northwestern North America (Hallingbäck et al., 2008). This species is more common in the northern part of Europe, growing mainly on deciduous trees (Frey et al., 2006). This species is endangered in Finland, rare in Latvia and in Lithuania (Hodgetts, 2015).

\section{Sphagnum Divinum Flatberg \& Hassel [varju-} turbasammal]

Voucher specimen: TU173223, Lääne-Viru Co., Vinni Comm., Kõrma village, Palasi drained mire at the edge of Sirtsi bog, transitional bog forest, on hummock $\left(59.25113^{\circ} \mathrm{N}, 26.75433^{\circ} \mathrm{E}\right)$, leg. K. Vellak, 12 July 2018; det. K. Vellak, 09 September 2018.

The actual distribution of $S$. divinum still needs clarification, but it is one of the most widely distributed peatmoss in Europe, with a circumboreal distribution in the Northern Hemisphere, growing typically in minerotrophic fen forests (Laine et al., 2018).

\section{Sphagnum medium Limpr. [raba-turbasammal]}

Voucher specimen: TU168386, Jõgeva Co., Jõgeva Comm., Endla Nature Reserve, Kaasikjärve bog, open bog community $\left(58.85672^{\circ} \mathrm{N}\right.$, $\left.26.21977^{\circ} \mathrm{E}\right)$, leg. K. Vellak, 07 July 2011 ; det. K. Vellak, 28 August 2018. This specimen was designated as the voucher specimen for $S$. $m a-$ gellanicum in 2015 (Vellak et al., 2015), but was re-identified as $S$. medium during this study.

Sphagnum medium has amphi-atlantic distribution, growing in raised bogs in temperate zones of northern hemisphere (Hassel et. al., 2018; Laine et al., 2018).

SYNTRICHIA RURALIS var. EPILOSA (Venturi) J.J. Amann

Voucher specimen: TALL D018368, Saare Co., Saaremaa Comm., Vilsandi Nature Park, Islet Harilaid, west coast, sand dunes in south from 
Kiipsaare, on sand $\left(58.49^{\circ} \mathrm{N}, 21.84417^{\circ} \mathrm{E}\right)$, leg. L. Kannukene, 03 July 1997; det. M. J. Cano, 21 May 2018.

The distribution and ecology of this variety is still unclear and needs further study. Up to now, it has been recorded only from three countries of Europe - Switzerland, Sweden and France (Callego et al., 2018). Estonia is the forth country for this variety in Europe.

\section{ULOTA CRISPULA BRUCH [SUJUV SÄBRIK]}

Voucher specimen: TU170149, Pärnu Co., Tori Comm., Taali forest square 94/8. Swamp forest, on a tree trunk $\left(58.433^{\circ} \mathrm{N}, 24.9^{\circ} \mathrm{E}\right)$, leg. M. Leis 29 August 1998; det. K. Vellak, R. Caparrós Callejo, 13 February 2019.

This corticolous species has amphi-atlantic distribution (Caparrós et al., 2016) reaching its eastern border of distribution in European Russia (Fedosov \& Ignatova 2018). One specimen (TU171433) from J. Mikutowicz's collection, collected in 1910 from the territory of current Latvia (Sussikas, Kreis Wolmar Vecmuiža, Salacgrivas County) was originally labelled as U. crispula and we confirmed this identification. We identified another specimen, originally determined as $U$. crispa (TU179103), and collected from Lithuania in 1994 as $U$. crispula. Therefore, we can conclude that $U$. crispula occurs in all Baltic countries, but its overall distribution still needs further investigations, because this taxon has not been accepted as a separate species for a long time.

UlOTA INTERMEDIA Schimp. [vahelmine säbrik]

Voucher specimen: TU173060, Järva Co., Türi Comm., Saeveski Landscape Reserve, old humid nemoral mixed forest near Saarjõe river, on a branch of Picea abies $\left(58.63342^{\circ} \mathrm{N}, 25.28565^{\circ} \mathrm{E}\right)$, leg. K. Vellak, 27 May 2017; det. R. Caparrós Callejo, 23 January 2018.

This species has wider but fragmented distribution area compared to previous species. Its distribution area ranges from western North America to Japan (Caparrós et al., 2016) and the species inhabits deciduous as well as coniferous trees. There is one $U$. crispa specimen (TU171435) among J. Mikutowicz collection that was collected from southern Latvia (Moritzholm, prev. Kurland), we identified this as $U$. intermedia. The actual distribution of $U$. intermedia needs clarification, especially because the great majority of former $U$. crispa specimens have been re-identified as $U$. intermedia in Russia (Fedosov \& Ignatova, 2018). Also in our study the overwhelming part of $U$. crispa specimens were re-identified as $U$. intermedia.

\section{New voucher specimens}

Atrichum CRISPUm (James.) Sull. [pehme kadrisammal]

Voucher specimen: TAA5000234, Ida-Viru Co., Illuka Comm., Agusalu Nature Reserve, SO from Kamarna, primeval fresh boreal forest, on ground $\left(59.11028^{\circ} \mathrm{N}, 27.57806^{\circ} \mathrm{E}\right)$, leg. P. Lõhmus, 10 April 2006, det. M. Leis, K. Vellak, N. Ingerpuu, 26 May 2017, ver. N. Hodgetts, 06 August 2017.

The previous voucher specimen (TU157121) designated in 2015, was identified as Polytrichum longisetum Sw. ex Brid. (det. N. Ingerpuu, 25 May 2017).

Dicranella Rufescens (Dicks.) Schimp. [ruuge kaksikhambake]

Voucher specimen: RIG (Fig. 1), Võru Co., Võru Comm., Urvaste. Near Kurenurme railway station, on ditch bank on clayey soil $\left(57.83869^{\circ} \mathrm{N}\right.$, $\left.26.769877^{\circ} \mathrm{E}\right)$, leg. W. J. Reinthal, 26 October 1930, det. unknown; ver. N. Ingerpuu, 25 April 2018.

Duplicate in the Natural History Museum of the University of Tartu (TU178652).

Plagiothecium latebricola Schimp. [varjupõikkupar]

Voucher specimen: TU169488, Pärnu Co., Häädemeeste Comm., Nigula Nature Reserve, primeval forest Salupeaksi, on a decaying log among hepatics $\left(58.02083^{\circ} \mathrm{N}, 24.67^{\circ} \mathrm{E}\right)$, leg. P. Lõhmus, 01 August 2006, det. K. Vellak, 2007, ver. T. Kupper, 10 October 2018.

The previous voucher specimen (TU167089) designated in 2015, has been identified as Plagiothecium laetum Schimp. (det. G. J. Wolski and T. Kupper, 10 October 2018).

Ulota CRISPa (Hedw.) Brid.

Voucher specimen: TALL D010736, Saare Co., Leisi comm., Karja parish, hazel woodland near Metsaääre, on trunk of a dead hazel 


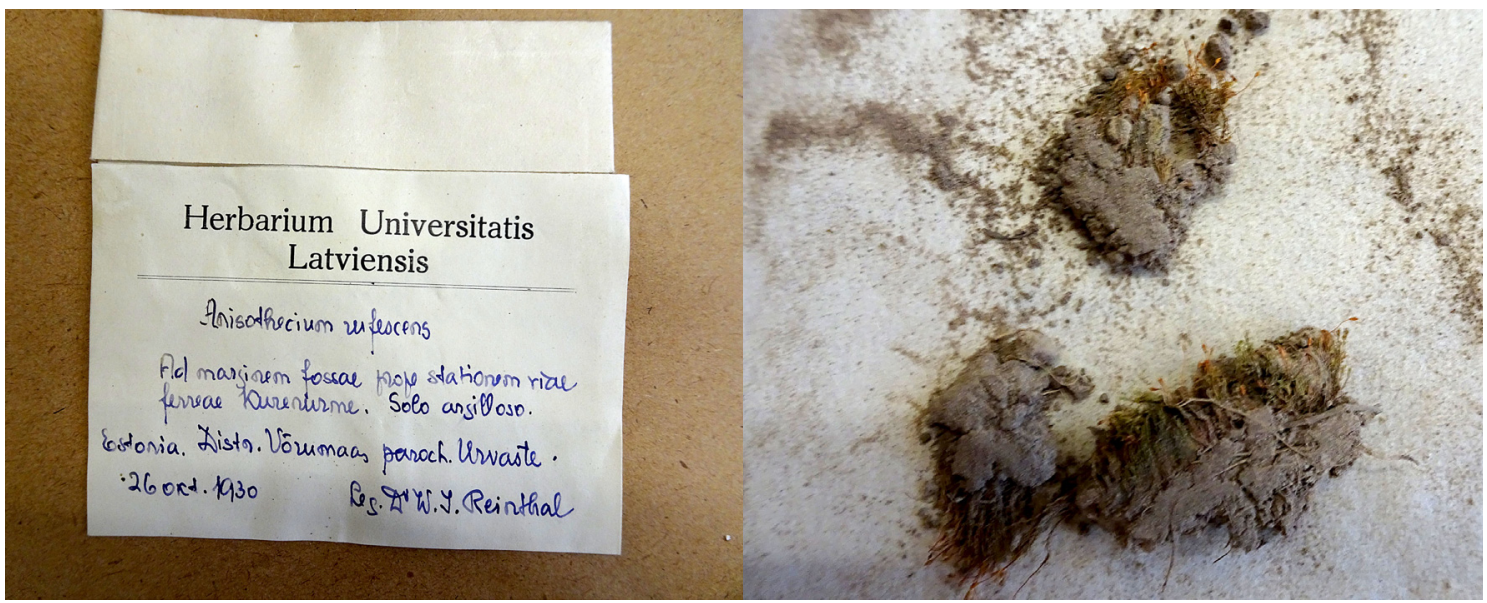

Fig. 1. Specimen of Dicranella rufescens (old synonym Anisothecium rufescens), collected from Estonia in 1930 by D. W. J. Reinthal and deposited in the Herbarium of the University of Latvia (RIG). Photo N. Ingerpuu.

$\left(58.48781^{\circ} \mathrm{N}, 22.78806^{\circ} \mathrm{E}\right)$, leg. L. Kannukene, 30 June 1981, det. L. Kannukene, 01 July 1981, ver. T. Kupper, M. Leis, 14 February 2019.

The previous voucher specimen (TAA5003879) designated in 2015, has been identified as Ulota intermedia Schimp. (det. M. Leis, 25 February 2019).

\section{ACKNOWLEDGEMENTS}

We are thankful to Dr. M. J. Cano for identifying the Syntrichia specimen and to Lena Gerz and Tea Tullus for their help with examining of Ulota specimens in TALL.

\section{REFERENCES}

Gallego, M.T., Vincent Hugonnot \& V. Cano, M. J. 2018. Taxonomic resurrection of an awnless variety of Syntrichia ruralis and comparison with other European muticous taxa in this genus. Journal of Bryology 40(3): 244-250. https://doi.org/10. 1080/03736687.2018.1468971

Caparrós, R., Lara, F., Draper, I., Mazimpaka, V. \& Garilleti, R. 2016. Integrative taxonomy sheds light on an old problem: the Ulota crispa complex (Orthotrichaceae, Musci). Botanical Journal of the Linnean Society 180: 427-451. https://doi. org/10.1111/boj.12397

Fedosov, V. E. \& Ignatova, E. A. 2018. On the genus Ulota (Orthotrichaceae, Bryophyta) in Russia. Novosti Sistematiki Nizshikh Rastenii 52(1): 141-171.
Frey, W., Frahm, J.-P., Fischer, E. \& Lobin, W. 2006. The liverworts, mosses and ferns of Europe. Gustav Fischer Verlag, Heidelberg. 512 pp.

Girgensohn, G.K. 1860. Naturgeschichte der Laub- und Lebermoose Liv-, Ehst- und Kurlands. Archiv für der Naturkunde Liv-, Ehst- und Kurlands 2(2): $1-488$.

Hallingbäck, T., Lönnell, N., Weibull, H., von Knorring, P., Korotynska, M., Reisborg, C. \& Birgersson, M. 2008. Nationalnyckeln till Sveriges flora och fauna. Bladmossor: Kompaktmossor - Kapmossor. Bryophyta: Anoectangium - Orthotrichum. ArtDatabanken, SLU, Uppsala. 366 pp.

Hassel, K., Kyrkjeeide, M.O., Yousefi, N., Prestø, T., Stenøien, H.K., Shaw, J.A. \& Flatberg, K.I. 2018. Sphagnum divinum (sp. nov.) and S. medium Limpr. and their relationship to S. magellanicum Brid. Journal of Bryology 3: 197-222. https:/ / doi. org/10.1080/03736687.2018.1474424

Hodgetts, N.G. 2015. Checklist and country status of European bryophytes - toward a new Red List of Europe. Irish Wildlife Manuals 84: 1-125. https:// www.npws.ie/sites / default/files / publications / pdf/IWM84.pdf

Laine, J., Flatberg, K.I., Harju, P., Timonen, T., Minkkinen, K., Laine, A., Tuittila, E.-S., \& Vasander, H. 2018. Sphagnum mosses - The Stars of European Mires. University of Helsinki Department of Forest Sciences, Sphagna Ky, Helsinki. 326 pp.

Malta, N. 1930. Übersicht der Moosflora des Ostbaltischen Gebietes. II. Laubmoose (Andreaeales et Bryales). Acta Horti Botanici Universitatis Latviensis 5(1/3): 75-104.

Rosman-Hartog, N. \& Touw, A. 1987. On the taxonomic status of Ulota bruchii Hornsch. ex Brid., 
U. crispa (Hedw.) Brid. and U. crispula Bruch ex Brid. Lindbergia 13: 159-164.

Russow, E. 1894. Zur Kenntnis der Subsecundumund Cymbifoliumgruppe europäisher Torfmoose. Archiv für der Naturkunde Liv-, Ehst- und Kurlands 10(4): 362-527.

Vellak, K., Ingerpuu, N., During, H., Flatberg, K.I., Leis, M., Ehrlich, L., Kannukene, L. \& Kupper,
T. 2017. New Estonian records: mosses. Folia Cryptogamica Estonica 54: 143-145. https:/ / doi. org/ 10.12697 / fce.2017.54.17

Vellak, K., Ingerpuu, N., Leis, M. \& Ehrlich, L. 2015. Annotated checklist of Estonian bryophytes. Folia Cryptogamica Estonica 52: 109-127. https:/ / doi. org/ 10.12697 /fce.2015.52.14 
Folia Cryptog. Estonica 